\title{
Performance evaluation of optimization models in the determination of wastewater treatment efficiencies inside watersheds
}

\section{Avaliação de modelos de otimização aplicáveis à determinação de eficiências de tratamento de efluentes no âmbito de uma bacia hidrográfica}

\author{
Mariana Coelho Santoro ${ }^{1}$, José Antonio Tosta dos Reis ${ }^{1}$ and Antonio Sérgio Ferreira Mendonça ${ }^{1}$ \\ ${ }^{1}$ Universidade Federal do Espírito Santo, Vitória, ES, Brasil \\ E-mails: marianacsantoro@gmail.com (MCS),jatreis@gmail.com (JATR), anserfm@terra.com.br (ASFM)
}

Received: March 07, 2016 - Revised: May 21, 2016 - Accepted: June 20, 2016

\begin{abstract}
Determination of sewage treatment plants pollutant removal efficiencies, considering the protection of water resources, is very difficult because it involves complex analysis that must take into account multiple discharges into watercourses presenting different self depuration capacities. The research aimed to evaluate different optimization models for determination of minimum sewage treatment efficiencies for plants located in a watershed. The analyzed optimization models involves minimization of the sum of treatment efficiencies and minimization of inequity between sewage treatment efforts. Water quality mathematical model and Genetic Algorithm were combined in a MatLab software computing environment. The Pardo river watershed is the study area. Pardo river is a tributary of the Itapemirim river, important watercourse located in the southern part of Espirito Santo State, in Brazil. The results indicate that the optimization models that incorporate measurement of equity as a problem restriction did not generate consistent answers, probably because of the wide range of sewage loads values considered in the Pardo river watershed. The models that incorporate equity measures in the objective function showed satisfactory performance and resulted in very close values for minimum sewage treatment efficiencies.
\end{abstract}

Keywords: Optimization; Genetic algorithms; Water quality modeling; Wastewater.

\section{RESUMO}

A escolha de eficiências de estações de tratamento de esgotos é complexa quando avaliada no âmbito de bacias hidrográficas, função dos múltiplos lançamentos, de diferentes cargas, dispostos em corpos d'água com diferentes capacidades de assimilação. Esta pesquisa teve como objetivo avaliar modelos de otimização aplicáveis à determinação de eficiências mínimas de tratamento de esgotos no âmbito de uma bacia hidrográfica. Os modelos de otimização avaliados consideraram a minimização do somatório das eficiências e a minimização da inequidade entre os esforços de tratamento de esgotos. Um modelo matemático de qualidade de água e o Algoritmo Genético foram combinados no ambiente computacional do software MatLab, o que permitiu a obtenção de eficiências mínimas de tratamento de esgotos a partir dos modelos de otimização utilizados. A bacia hidrográfica do rio Pardo, afluente do rio Itapemirim - importante curso d'água da porção sul do estado do Espírito Santo - constituiu a área de estudo. Os resultados indicaram que os modelos de otimização que incorporam medida de equidade como restrição do problema não apresentam respostas consistentes, função da grande variação de carga orgânica bruta existente nos efluentes produzidos na bacia hidrográfica do rio Pardo. Os modelos que incorporaram medidas de equidade na função objetivo apresentaram desempenho satisfatório e permitiram a obtenção de conjuntos de eficiências de tratamento de esgotos próximos entre si.

Palavras-chave: Otimização; Algoritmo genético; Modelagem de qualidade de água; Efluente. 


\section{INTRODUCTION}

Some activities that make part of water resources planning and management processes are intended to adjust water bodies availability and quality to demand patterns established by different possible uses.

As support tools for decision-making processes related to planning and management of water resources, water quality models are widely used to evaluate $\boldsymbol{a}$ ) the spatial and temporal evolution of water bodies quality and $\boldsymbol{b}$ ) the effects of final disposal of raw or treated domestic or industrial effluents. The works of Albertin, Mauad and Daniel (2006), Paliwal, Sharma and Kansal (2007), Zhang et al. (2012), Salla et al. (2013) and Teodoro et al. (2013), for example, illustrate how water quality mathematical models can support planning and/or management processes within river basins.

Implementation of sewage treatment plants is usually the main structural measure adopted for Brazilian rivers water quality improvement. The selection process of sewage treatment plants becomes more complex when viewed from the standpoint of a watershed that presents multiple releases of different loads in water bodies presenting different self depuration capacities (REIS; VALORY; MENDONÇA, 2015).

In this context water quality models, even indispensable, may have use limitations due to the diversity of alternatives that require evaluation. Thus, the combined use of water quality models and optimization techniques have received attention from various authors such as Cho et al. (2004), Aras, Togan and Berkun (2007), Saadatpour and Afshar (2007) and Carvalho and Kaviski (2009), that deal with the definition of treatment efficiencies for sewage plants located in different watersheds.

In the optimization field, the Metaheuristics techniques techniques that, in the search process for solutions, incorporate structured stochastic elements and follow guidelines often inspired by natural phenomena - have allowed different applications in the water resources planning and management area (NICKLOW et al., 2010). Among the metaheuristics techniques, Genetic Algorithms (GA) have enabled applications in various fields such as urban drainage, sewage collection (TSAI; CHANG, 2001; PENN; FRIEDLER; OSTFELD, 2013), water supply and effluent treatment systems (PARK; KO; LEE, 2007; SAADATPOUR; AFSHAR, 2007; HOLENDA et al., 2007).

In the sewage treatment systems selection process there are recurrent conflicts involving water bodies quality improvement, effluents treatment costs minimization and equity between polluting sources treatment efforts (ANDRADE; MAURI; MENDONÇA, 2013).

Minimization of wastewater treatment costs is usually related to minimization of stations pollutants removal efficiencies, considering that receiver bodies water quality standards are ensured. Since in Brazil the implementation of sewage treatment plants (WWTP) is generally a government task, reduction of treatment efforts - with the consequent reduction of investments for stations implementation and operation - can allow that saved public funds be directed to other social demands (REIS; VALORY; MENDONÇA, 2015).

However, when equity is not considered in the pursuit of the minimization of the sum of the efficiencies of the sewage treatment plants located in a watershed, users who are located more downstream need to magnify treatment efforts, since the river can present certain level of degradation caused by releases located upstream. There is also the possibility that flows downstream are much higher than the flows upstream, depending on entries and tributaries incremental flows, causing the need for greater treatment efficiencies for users who are closer to the rivers headwaters, even if the sewage loads discharged by them is similar to those originated by users that are located closer to the river mouth. It can also occur that inexpressive users are demanded to treat their effluents through high pollutant removal efficient systems, when more important pollution sources located further upstream produce higher degradation of the water body. Finally, it should be noted that in Brazil - as well as in various parts of the world - raising resources for sanitation is related to collection of sewage fees from households connected to sewage collection and treatment networks and that the pursuit of equity can avoid imbalances by the adoption of very different solutions in terms of investments and works for different communities in the same watershed. The search for alternatives to ensure equity between sewage treatment systems has been subject of works such as Burn and Yulianti (2001), Yandamuri et al. (2006), Andrade, Mauri and Mendonça (2013), Cho and Lee (2014), Reis, Valory and Mendonça (2015), Valory, Reis and Mendonça (2015).

Within this approach, this work presents as main objective the evaluation of the performance of optimization models for minimizing wastewater treatment efforts within a river basin, while attempting to fulfill water quality standards and pursuing equity between different treatment plants efficiencies. The AG, integrated with a water quality model was used to solve the optimization problem. The models were applied to the Pardo River basin. Pardo is an Itapemirim river tributary. This river is an important watercourse located in the southern portion of the Brazilian Espirito Santo state.

\section{STUDY AREA}

The optimization models were applied to the Pardo river basin (Figure 1), located on the upper portion of the Itapemirim river watershed, in Espírito Santo state, Brazil.

The Pardo river basin encompasses the municipalities of Ibatiba and Irupi, two districts - Santíssima Trindade and Nossa Senhora das Graças - and the municipal seat of Iúna. The water basin presents 573 square kilometers drainage area and a population of about 55,528 inhabitants, according to the IBGE projection for the year 2014 (IBGE, 2011).

The Pardo river basin does not present any operating sewage treatment plant. The Pardo river is a direct recipient of the wastewater produced in the urban areas of Ibatiba and Iúna cities. The main Pardo river tributaries that receive urban raw domestic effluents are Pardinho river, which receives the sewage produced by urban Irupi and Perdição stream, receiving sewage produced in the localities of Santíssima Trindade and Nossa Senhora das Graças.

A single-line diagram of the basin water system, including the main effluents disposal points, is shown in Figure 2. 


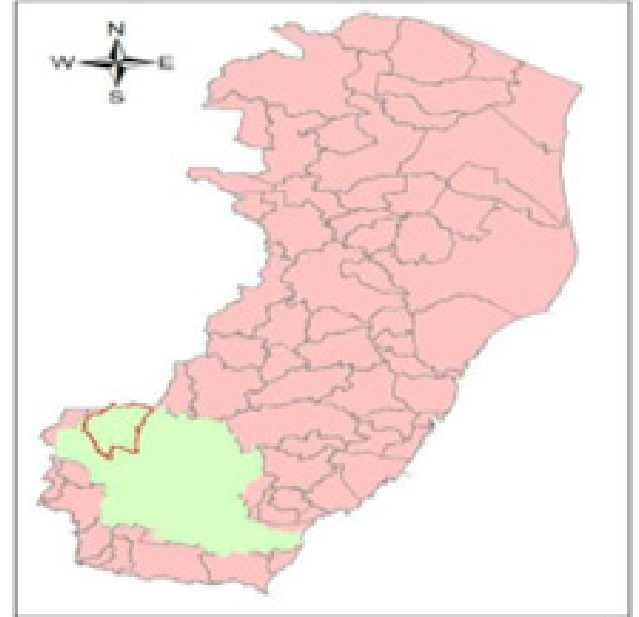

\section{Espirito Santo State}

\section{Itapemirim river watershed}

\section{Pardo river basin}
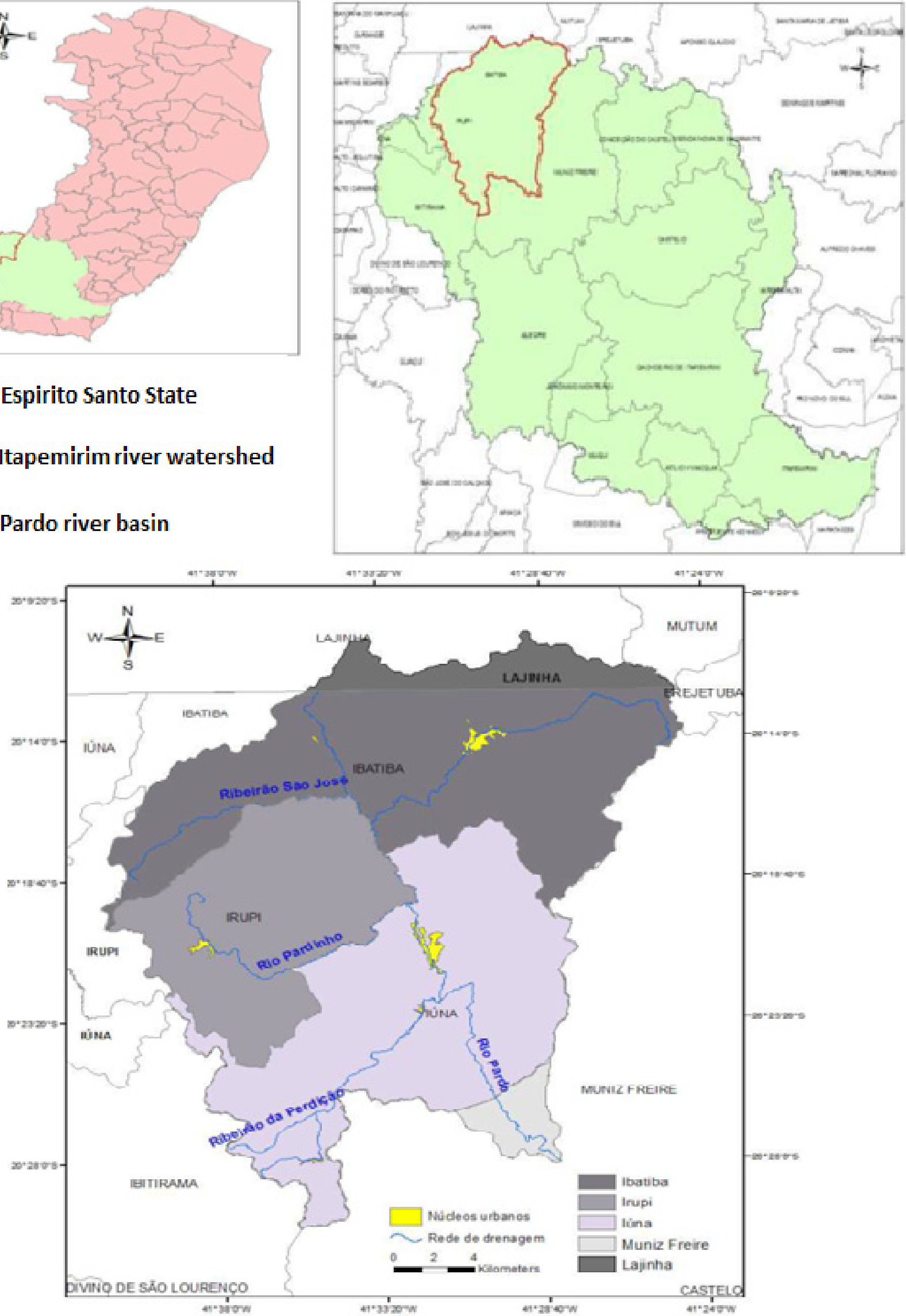

Figure 1. Pardo River basin Localization. 


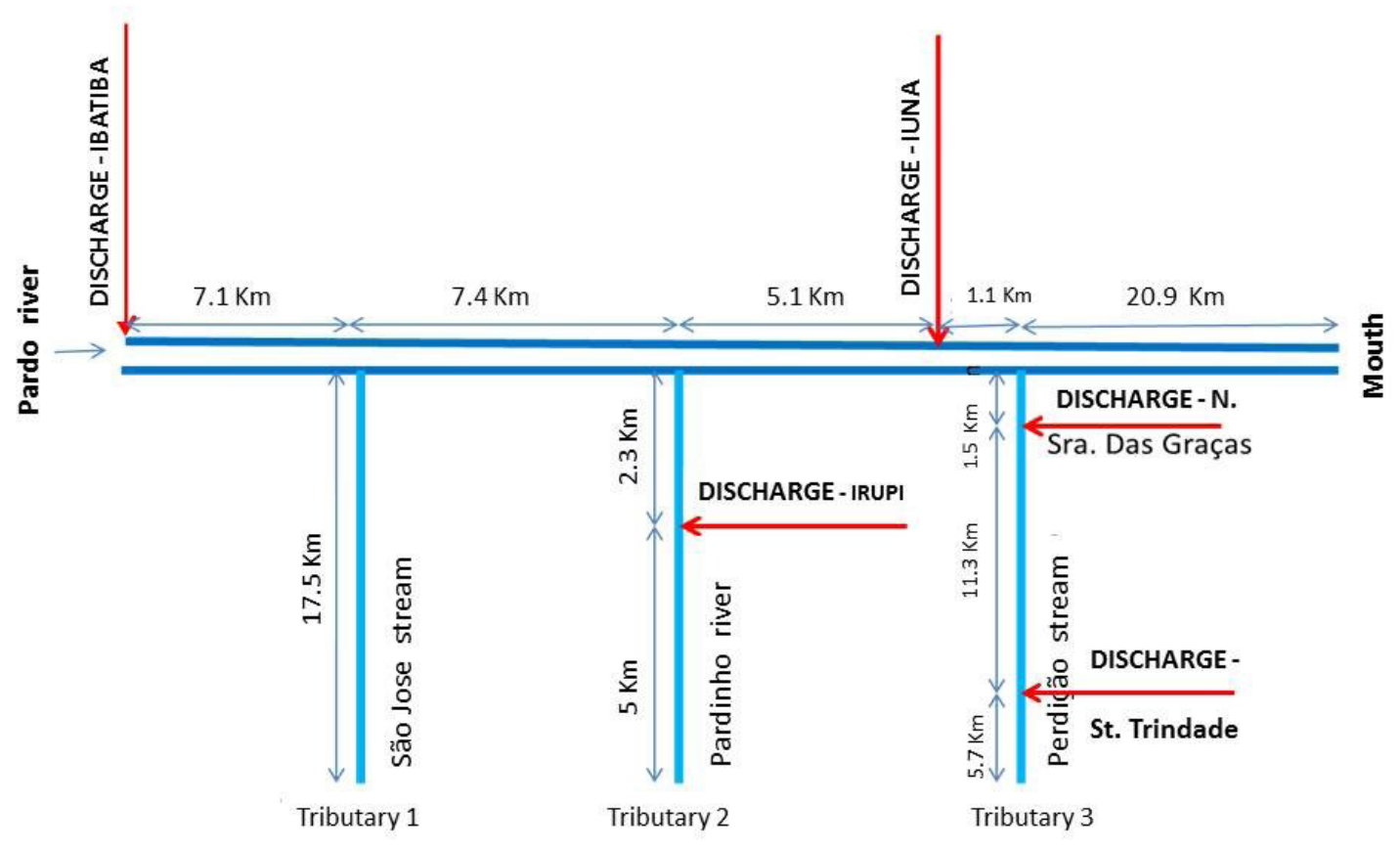

Figure 2. Pardo River watershed single-line diagram.

\section{MATERIALS AND METHODS}

\section{Water quality modeling}

In this study, water quality modeling was conducted by using the computational model developed in MatLab software environment by Valory (2013). In order to be adapted to the Pardo river basin, that model has been modified to allow water quality simulations both in the main river and in its tributaries and incorporation of diffuse loads of pollutants throughout the water system. The water quality model developed by Valory (2013) - as well as the resulting from the changes made in this work - reproduces the conceptual and computational mathematical formulations and structures of the QUAL-UFMG model, originally presented and discussed by Von Sperling (2007).

The simulated water quality parameters were Biochemical Oxygen Demand (BOD) and Dissolved Oxygen (DO), constituents usually utilized to characterize water bodies quality after receiving domestic sewage discharges.

Relations between hydrodynamic variables and terms applicable to the estimate of deoxygenation and reaeration coefficients and organic loads were obtained from the work produced by Calmon et al. (2016), when employing water quality permanence curves to evaluate Pardo river use of water classification alternatives, according to Brazilian legislation.

In their study, Calmon et al. (2016) determined values of the kinetic constants and hydrodynamic variables for the Pardo river from the results of systematic flows monitoring performed in Terra Corrida fluviometric station, operated by the Brazilian National Water Agency (ANA).

Pardo river drought conditions allowed Calmon et al. (2016) estimate river deoxygenation coefficient, $K_{1}$, by using expression proposed by EPA (1985) and Thomann and Mueller (1987). For appropriation of $\mathrm{K}_{2}$ it was used expression proposed by O’Connor and Dobbins (1958).

The domestic wastewater organic load generated by the resident population of the three cities and two districts located in the Pardo River basin was separated according to the origin, rural or urban, representing two different forms of water pollution. It was assumed, in favor of safety, that all wastewater from the rural population would reach water bodies without any kind of treatment, generating a direct incremental BOD load to all reaches of the Pardo. Pardinho, Perdição and São José watercourses. The direct incremental BOD load, also estimated by Calmon et al. (2016), assumed the value $9.35 \mathrm{gBOD} \cdot \mathrm{day}^{-1} \cdot \mathrm{m}^{-1}$.

For urban wastewater it was adopted the BOD concentration $400 \mathrm{mg} \cdot \mathrm{L}^{-1}$ and per capita share $145 \mathrm{~L}$. inhabitant ${ }^{-1}$.day ${ }^{-1}$. From the number of inhabitants of urban perimeters, considering that all domestic wastewater would be collected, there were estimated the sewage flows generated. From the fact that there are no operating sewage treatment plants in the Pardo river basin, the raw sewage produced by municipalities urban populations would constitute point pollution releases to the water system.

Population data, effluents flow and raw organic loads considered in this study are presented on Table 1 . These values were obtained from population data estimated by Calmon et al. (2016) for the year 2030, based on population growth geometric progression presented by IBGE (2011).

\section{Genetic algorithm}

Valory, Reis and Mendonça (2015), for estimating minimum treatment efficiencies for hypothetical scenarios of sewage disposal in the upper portion of the Santa Maria da Vitória river (Espírito 
Table 1. Domestic effluents flow generated by urban population of the Pardo River Basin.

\begin{tabular}{lccc}
\hline \multicolumn{1}{c}{ Urban core } & Urban population (inhabitants, 2030) & Urban flow discharge (L.s ${ }^{\mathbf{1}}$ ) & Raw $^{\text {Organic Load (Kg.d }}{ }^{\mathbf{1}}$ ) \\
\hline Ibatiba & 18125 & 24.33 & 840 \\
Irupi & 4918 & 5.24 & 180 \\
Iúna & 14821 & 19.90 & 690 \\
N. Sa das Graças & 600 & 0.64 & 22 \\
St ${ }^{\text {a }}$ Trindade & 301 & 0.32 & 11 \\
\hline
\end{tabular}

Santo state), tested different operators for the AG. In this work there were employed operators and parameters presented as the best by these authors, summarized as follows:

\section{- Real-Coding;}

- Arithmetic crossover, in which the daughter chromosomes are generated by linear combination of the parents;

- Initial population of 300 (three hundred) individuals;

- $50 \%$ crossover rate;

- Type tournament selection;

- Adaptive Mutation;

- Preservation of three (3) individuals to elitism;

- Stopping criterion for convergence of results or limit of 100 generations.

For the application of $A G$ as optimization technique it was employed the Optimization toolbox from MatLab software.

\section{Optimization models}

The optimization models selected for estimating wastewater treatment efficiencies in the Pardo river basin were shaped by objectives and constraints functions that considered three different aspects: a) minimizing the sum of treatment efficiencies within the basin, b) minimizing the inequity between the treatment efforts associated with different treatment systems and c) the maintenance of environmental quality standards set for water bodies by the Brazilian National Environmental Council (CONAMA) in 357/2005 and 430/2011 resolutions (BRASIL, 2005, 2011).

In this context, we selected six (6) optimization models for conduction of this work. They are:

- Model 1: proposed by Valory, Reis and Mendonça (2015).

Minimize $f(E)=\sum_{i=1}^{n} E_{i}$

- Model 2: proposed by Reis, Valory and Mendonça (2015), that utilizes the same objective function defined by Equation 1, subject to restriction presented by Equation 2 .

$\frac{\text { Load }_{\text {Discharge i }}}{E_{i}}=\frac{\text { Load }_{\text {Discharge n }}}{E_{n}}, \forall$ i $\forall \forall n$

- Model 3: modification of the proposed by Valory, Reis and Mendonça (2015), employing the Equation 1 as objective function subject to the constraint given by Equation 3 .

$\frac{\text { Load }_{\text {Discharge i }}}{E_{i}{ }^{2}}=\frac{\text { Carga }_{\text {Lançamento } n}}{E_{n}{ }^{2}}, \forall$ ie $\forall n$
- Model 4: introduces equity measure in the objective function (Equation 4), as proposed by Mulligan (1991).

Minimize $f(E)=\sum_{i=1}^{n}\left[\left|\frac{\text { Load }_{\text {Discharge } i}}{\overline{\text { Load }_{\text {Discharge } i}}}-\frac{E_{i}}{\bar{E}}\right|\right]$

- Model 5: introduces equity measure in the objective function (Equation 5), as originally established by Marsh and Schilling (1994).

Minimize $f(E)=\sum_{i=1}^{n} \sum_{i=j}^{n}\left|\left(\frac{\text { Load }_{\text {Discharge } i}}{E_{i}}\right)-\left(\frac{\text { Load }_{\text {Discharge } j}}{E_{j}}\right)\right|$

- Model 6: introduces equity measure in the objective function as proposed by Burn and Yulianti (2001).

Minimize $f(E)=\sum_{i=1}^{n}\left|\left(\frac{\text { Load }_{\text {Discharge } i}}{E_{i}}\right)-\left(\frac{\overline{\overline{\text { Load }_{\text {Discharge } i}}}}{\bar{E}}\right)\right|$

In the Expressions 1 to 6:

- Ei: treatment efficiency associated with discharge i;

- $\mathrm{E}_{\mathrm{n}}$ : treatment efficiency associated with discharge $\mathrm{n}$;

- $\operatorname{Load}_{\text {Discharge: }}$ : raw sewage organic load associated with the discharge $\mathrm{i}$ in kg.dia ${ }^{-1}$;

- $\operatorname{Load}_{\text {Discharge }}$ : raw sewage organic load associated with the discharge $\mathrm{j}$ in $\mathrm{kg} \cdot \mathrm{dia}^{-1}$.

The different optimization models, in addition to the original restrictions, incorporated the restrictions established by the Inequalities 7 and 8.

$E_{i} \geq 1$

$E_{i} \leq 95$

The Inequality 7 aims to ensure non-negative values for treatment efficiencies and Inequality 8 considers the value suggested by Von Sperling (2007) as the maximum BOD removal achieved by secondary sewage treatment systems.

For application of the selected optimization models there were considered, in addition, three groups of constraints, corresponding to the environmental standards set by CONAMA Resolution 357/2005 for freshwater bodies I, II and III use classes, according to Inequalities 9 to 14.

Group 1 simulations:

$D O_{\text {River }} \geq 6 \mathrm{mg} \cdot \mathrm{L}^{-1}$

$B O D_{\text {River }} \leq 3 \mathrm{mg} \cdot \mathrm{L}^{-1}$ 
Group 2 simulations:

$$
\begin{aligned}
& D O_{\text {River }} \geq 5 \mathrm{mg} \cdot \mathrm{L}^{-1} \\
& B O D_{\text {River }} \leq 5 \mathrm{mg} \cdot \mathrm{L}^{-1}
\end{aligned}
$$

Group 3 simulations:

$$
\begin{aligned}
& D O_{\text {River }} \geq 4 \mathrm{mg} \cdot \mathrm{L}^{-1} \\
& B O D_{\text {River }} \leq 10 \mathrm{mg} \cdot \mathrm{L}^{-1}
\end{aligned}
$$

In the Inequalities 9 to 14 :

- $\mathrm{DO}_{\text {River }}$ : Dissolved Oxygen concentration in the watercourse;

- $\mathrm{BOD}_{\text {River }}:$ Biochemical Oxygen Demand concentration in the watercourse.

Although optimization models consider different water use classes, as established by the Inequalities 9 to 14, it is worth noting that because the Pardo basin water bodies were not classified by Espírito Santo Environmental Pollution Control Secretary they are provisionally considered as class II use rivers.

It is worth noting, additionally, that in this study there were not considered the maximum BOD value for treated wastewater (120 mg.. $\mathrm{L}^{-1}$ ) and the minimum BOD removal efficiency value $(60 \%)$ indicated by Brazilian CONAMA Resolution 430/2011, being assumed that all BOD load released could be assimilated as a result of watercourses self-purification capacity. This condition is accepted by the Resolution, by indicating that the maximum BOD concentration or minimal treatment efficiency can be ignored "[...] if watercourse depuration study proves compliance with the receiving body water use classification goal” (BRASIL, 2011, p. 3).

Reis, Valory and Mendonça (2015) noted that the imposition of quality standards for effluents by CONAMA Resolution 430/2011 led to higher treatment levels associated with the final effluent disposal points located in the upper Santa Maria da Vitória river, also located in Espírito Santo state.

\section{Equity analysis}

To evaluate the equity conditions set by the various optimization models, the Lorentz curve was utilized.

The Lorentz curve is a tool used in economics to analyze how equitable is a population income distribution. Curves are constructed in a cumulative percentage graph of family income versus cumulative population percentage, the population being ordered according to income per capita, from the lowest yield to the highest yield. Research has been developed about the use of Lorentz curve to assess inequities in distribution of environmental resources (DRUCKMAN; JACKSON, 2008) and allocation of specific wastewater discharges in river basins (SUN et al., 2010).

In this study, the Lorentz curve is used similarly as employed by Sun et al. (2010). It is considered the relationship between the raw organic loads associated with each effluent disposal point and organic loads removed when considering the systems treatment efficiencies generated by the optimization models applied to the Pardo river basin. Lorentz curve was plotted for each model, according to generic representation shown in Figure 3.

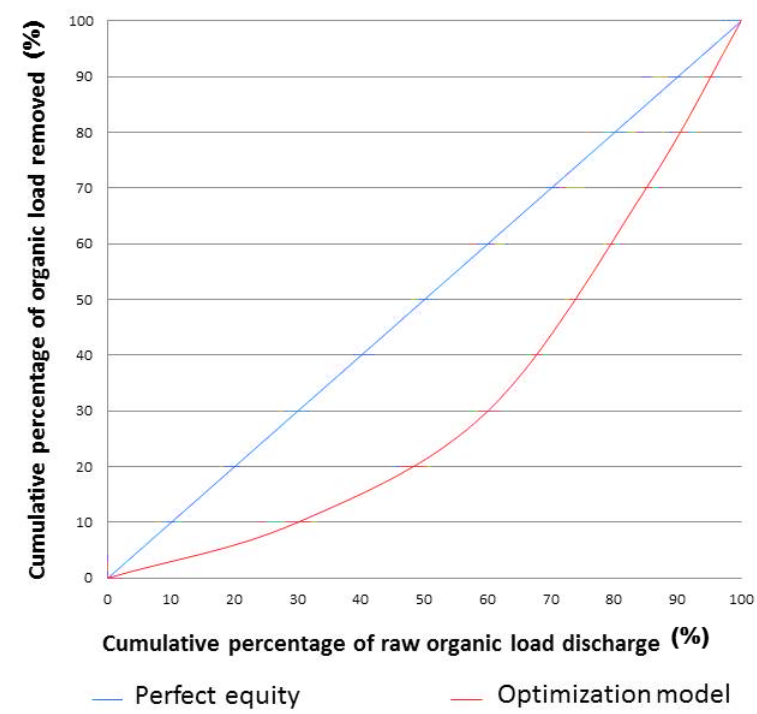

Figure 3. Generic representation of the Lorentz curves.

Since the treatment efficiency indicates the sewage organic matter removal percentage, the perfect equality is achieved when the treatment systems efficiencies are distributed proportionally between the release points, that is, higher organic loads correspond to allocation of treatment plants presenting higher organic matter removal efficiencies.

\section{RESULTS AND DISCUSSION}

\section{Water quality modeling}

With the help of water quality model, DO and BOD parameters profiles were generated considering raw sewage release into the Pardo (Figure 4), Pardinho (Figure 5) and Perdição watercourses (Figure 6). The highlighted lines in Figures 4, 5 and 6 represent the quality standards established for Class II use rivers. However, the optimization models could consider any other water use classes.

From simple inspection of the OD and BOD profiles, the following considerations are relevant:

- Pardo river DBO profile presents concentration peaks when receiving effluents generated by Ibatiba (kilometer zero) and Iúna (twenty kilometers) municipalities. São José stream receives no sewage point release and when it discharges into Pardo River (approximately at $\mathrm{km} 7$ ) its organic matter is diluted. Pardinho river, which receives Irupi city effluent, also contributes with Pardo river flow increase without, however, produce BOD concentration increase. This condition is established because of Pardinho river self-purification upstream its confluence with the Pardo river. Perdição stream, in turn, produces little dilution of the organic matter, producing the BOD concentration reduction that occurs at kilometer 21 . It should be noted, 

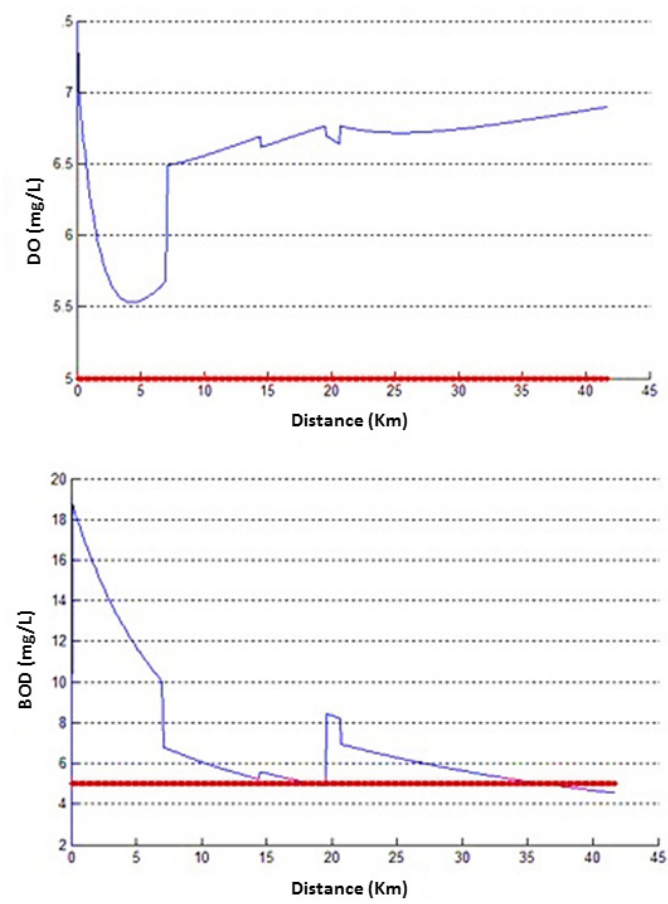

Figure 4. Pardo river DO and BOD concentration profiles.
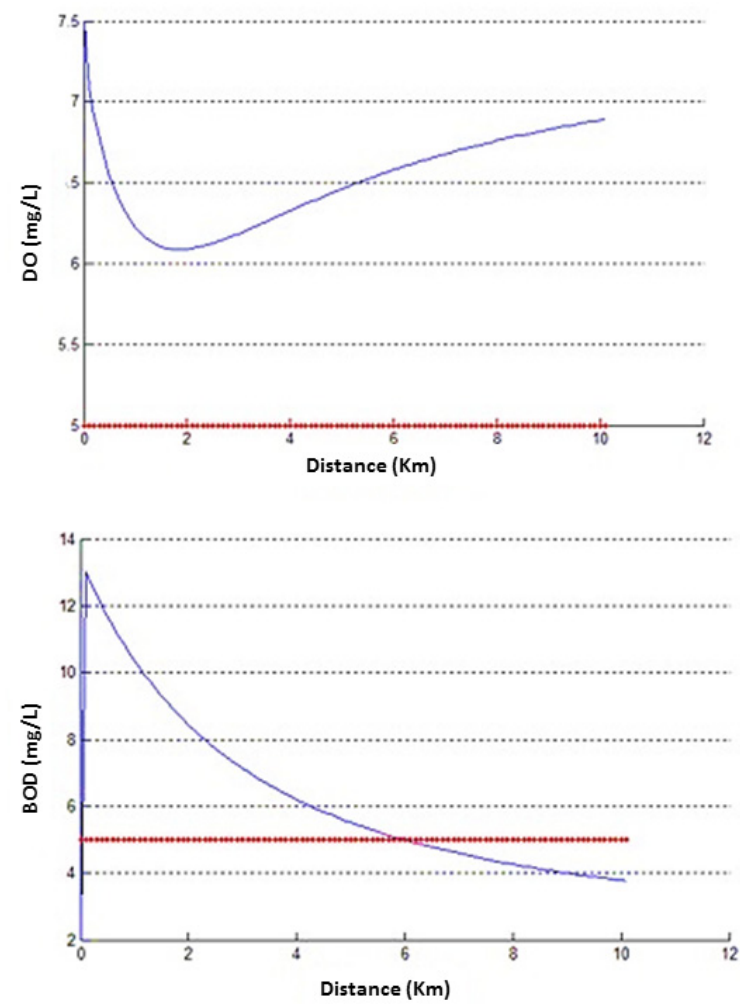

Figure 5. Pardinho river DO and BOD concentration profiles. however, that the class II rivers quality standard for BOD is only attended at the final portion of the Pardo river, downstream kilometer 37 .

- Pardo river OD profile presents more significant variations due to the disposal of Ibatiba raw sewage. It is relevant to note, additionally, that the simulated DO concentrations for the entire length of the watercourse is superior to the quality standard established for Class II rivers uses by CONAMA Resolution 357/2005.

- Raw sewage from Irupi city is discharged into The Pardinho river, causing considerable BOD concentration increase. The maximum simulated BOD corresponds to, approximately, $13 \mathrm{mg} . \mathrm{L}^{-1}$. Water quality conditions simulations, however, showed little change in DO concentration values along the whole length of the river, being always estimated DO concentrations above $6 \mathrm{mg} \cdot \mathrm{L}^{-1}$. Function of the depuration process, the BOD concentration estimated for Pardinho river mouth was less than 4 mg. $\mathrm{L}^{-1}$.

- Function of their small populations, Santíssima Trindade and Nossa Senhora das Graças districts discharge little significant organic loads in the Perdição stream creek. As a result, effluents produce small change in its water quality, raising the BOD concentration from 2 to close to $3 \mathrm{mg} . \mathrm{L}^{-1}$. The simulated DO levels, in turn, is maintained close to the initial levels and always greater than $7 \mathrm{mg} \cdot \mathrm{L}^{-1}$.
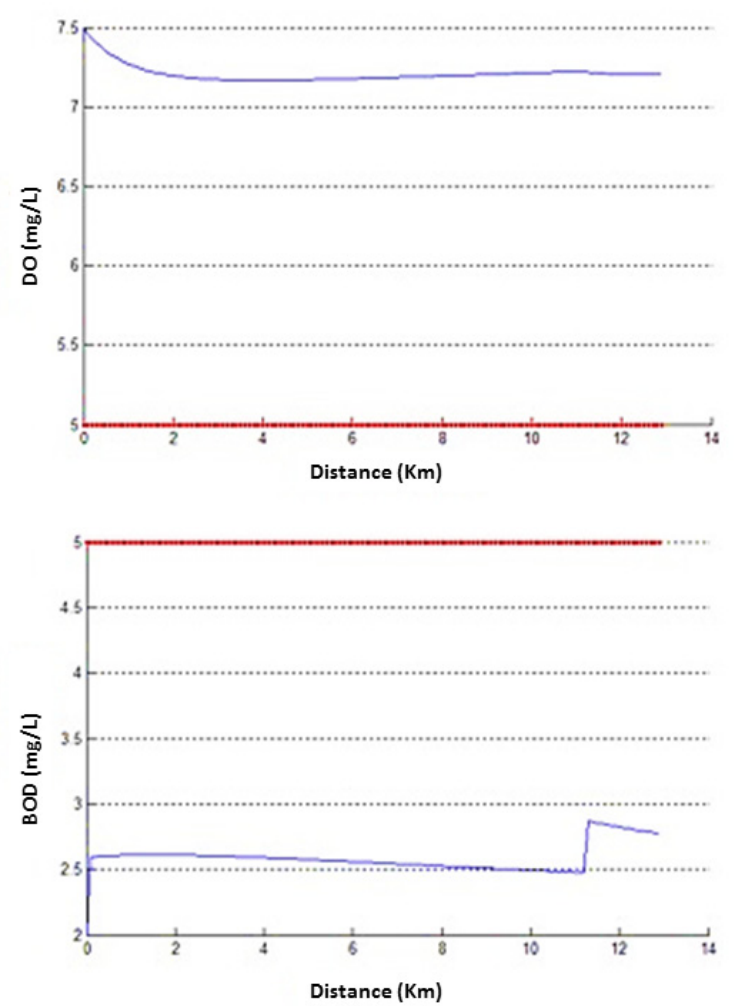

Figure 6. Perdição stream DO and BOD concentration profiles. 


\section{Treatment efficiencies of raw sewage generated by optimization models}

For the determination of the minimum sewage treatment efficiencies there were conducted, for each set of environmental quality standards (groups of simulations) and each optimization model, five simulations. Of the five efficiency sets generated with the aid of the combined use of the water quality model and $A G$ it was selected, by group of simulations, one that showed lower sum of efficiencies within the basin.

It is important to note that because AG constitutes an optimization metaheuristic technique there is no guarantee that the results obtained with the help of the algorithm necessarily achieved the global optimum or reproducibility. The realization of different simulations mitigated this difficulty, since the obtaining of same or similar results indicates that the global optimum has been reached or a value close to the global optimum was found.

According to Von Sperling (2007), primary and secondary sewage treatment systems present minimal BOD removal efficiency, less than, approximately, 25\%. From this perspective, in the following tables all estimated efficiencies with values lower than $25 \%$ are shown in parentheses, next to the symbol " $<25$ ".

\section{Optimization model 1}

Optimization Model 1 was the only analyzed that did not use equity measures in the set of constraints or objective function. Model 1 objective function (Equation 1) sought only the minimization of the Pardo river basin sum of wastewater treatment efficiencies. The main objective of the use of this optimization model was to allow the analysis of the variation of the efficiencies estimated through models that incorporate equity values in their conformation. The results from Optimization Model 1 are presented in Table 2 .

It is noted that significant sewage treatment efficiencies were estimated only for Ibatiba and Irupi municipalities and the loads from the other locations would be assimilated by watercourses dilution and self-purification processes. The load discharged by Iúna municipality $\left(690 \mathrm{~kg} \cdot \mathrm{day}^{-1}\right)$, even with a substantially higher value than the corresponding to Irupi $\left(180 \mathrm{~kg} \cdot \mathrm{day}^{-1}\right)$, do not need to receive treatment. If Ibatiba and Irupi effluent were treated with the estimated efficiencies, the Pardo River water quality in Iúna effluent discharge point would allow the raw effluent corresponding to this city to be assimilated by the watercourse. It is relevant to note that in the Iúna sewage disposal section the Pardo river flows are considerably higher, due to increased basin contribution and entry of three tributaries that present small organic loads.

Table 2. ewage treatment efficiencies (\%) estimated by using Optimization Model 1.

\begin{tabular}{|c|c|c|c|c|c|c|}
\hline \multirow[b]{2}{*}{ Group } & \multicolumn{5}{|c|}{ Location } & \multirow[b]{2}{*}{$\sum \mathbf{E}$} \\
\hline & Ibatiba & Irupi & $\begin{array}{l}\text { N. S. } \\
\text { Graças }\end{array}$ & $\begin{array}{c}\text { St. } \\
\text { Trindade }\end{array}$ & Iúna & \\
\hline 1 & 94 & 91 & $<25(1)$ & $<25(1)$ & $<25(1)$ & 188 \\
\hline 2 & 82 & 73 & $<25$ (1) & $<25(1)$ & $<25(1)$ & 158 \\
\hline 3 & 52 & 27 & $<25$ (1) & $<25(1)$ & $<25(1)$ & 82 \\
\hline
\end{tabular}

\section{Optimization models 2 and 3}

Optimization models 2 and 3 aimed to minimize the sum of efficiencies, considering equity measures as models restriction (Equations 2 and 3). The results obtained with application of the optimization models 2 and 3 are presented in Tables 3 and 4, respectively.

Optimization models 2 and 3 did not allow the determination of minimum wastewater treatment efficiencies complying with a) the boundary conditions associated with group 1 simulations, and $\boldsymbol{b})$ the maximum BOD removal efficiency (95\%).

Estimates of sewage treatment efficiencies proposed by optimization models 2 and 3 , considering the restrictions on the group 1 simulations, were possible when the loads from the two districts presenting lower organic matter contribution - Nossa Senhora das Graças and Santissima Trindade - were excluded from the water quality modeling. The attempt to maintain equity between the treatment systems has required the AG to search for extreme efficiency values that could be compatible with the values of organic loads discharged by the different urban areas, ranging from $840 \mathrm{~kg}$.day ${ }^{-1}$, in Ibatiba, to $11 \mathrm{~kg}$.day ${ }^{-1}$, in Santissima Trindade. However, it was not possible to achieve equity between treatment systems according to Equations 2 and 3 (equity restrictions in Models 2 and 3, respectively) with the estimated efficiency values considering the 100 generations limit.

It is important to note that the efficiencies estimated for Nossa Senhora das Graças and Santissima Trindade districts with the help of Model 3 were larger than those estimated by using Model 2. This result is due to the prioritization of the efficiency variable in the objective function (in Equation 3, the efficiency term is squared), an aspect that resulted in reduction of the variability of the estimated efficiencies for different effluent disposal points located in the Pardo river basin.

Reis, Valory and Mendonça (2015) proposed the optimization Model 2 for determination of wastewater treatment efficiencies for hypothetical releases associated with the upper portion of Santa Maria da Vitoria river. In their study, five effluent discharges were arranged in the river Santa Maria da Vitoria main channel,

Table 3. Sewage treatment systems efficiencies (\%) estimated from the use of optimization Model 2.

\begin{tabular}{|c|c|c|c|c|c|c|}
\hline \multirow[b]{2}{*}{ Group } & \multicolumn{5}{|c|}{ Location } & \multirow[b]{2}{*}{$\sum \mathbf{E}$} \\
\hline & Ibatiba & Irupi & $\begin{array}{l}\text { N. S. } \\
\text { Graças }\end{array}$ & $\begin{array}{c}\text { St. } \\
\text { Trindade }\end{array}$ & Iúna & \\
\hline 1 & 95 & 91 & - & - & 91 & 277 \\
\hline 2 & 95 & 73 & $<25(9)$ & $<25(4)$ & 87 & 271 \\
\hline 3 & 95 & 27 & $<25(3)$ & $<25(2)$ & 79 & 212 \\
\hline
\end{tabular}

Table 4. Sewage treatment systems efficiencies (\%) estimated by using optimization Model 3.

\begin{tabular}{ccccccc}
\hline & \multicolumn{5}{c}{ Location } & \\
\cline { 2 - 6 } Group & Ibatiba & Irupi & $\begin{array}{c}\text { N. S. } \\
\text { Graças }\end{array}$ & $\begin{array}{c}\text { St. } \\
\text { Trindade }\end{array}$ & Iúna & \\
\hline 1 & 95 & 90 & - & - & 92 & 277 \\
2 & 95 & 73 & $<25(24)$ & $<25(18)$ & 89 & 299 \\
3 & 67 & 31 & $<25(11)$ & $<25(8)$ & 60 & 177 \\
\hline
\end{tabular}


presenting load variations of at most three times, an aspect that allowed equity ratio established by the Equation 2 attendance at the same time that the environmental quality requirements were ensured. It should be noted that in Pardo river basin the highest raw organic load (load produced by Ibatiba municipality urban population) amounts to approximately 76 (seventy-six) times the lowest raw organic load (load produced by the Santissima Trindade district urban population).

\section{Optimization models 4, 5 and 6}

In optimization Models 4, 5 and 6, equity measures conformed the objective function, whose value should be minimized. The restrictions in these models considered only water quality standards for the different use classes and efficiency treatment limits.

Table 5. Sewage treatment systems efficiencies (\%) estimated by using optimization Model 4.

\begin{tabular}{|c|c|c|c|c|c|c|}
\hline \multirow[b]{2}{*}{ Group } & \multicolumn{5}{|c|}{ Location } & \multirow[b]{2}{*}{$\sum \mathbf{E}$} \\
\hline & Ibatiba & Irupi & $\begin{array}{c}\text { N. S. } \\
\text { Graças }\end{array}$ & $\begin{array}{c}\text { St. } \\
\text { Trindade }\end{array}$ & Iúna & \\
\hline 1 & 95 & 90 & $<25(4)$ & $<25(2)$ & 95 & 286 \\
\hline 2 & 95 & 73 & $<25(1)$ & $<25(1)$ & 94 & 264 \\
\hline 3 & 94 & 28 & $<25(1)$ & $<25(1)$ & 71 & 195 \\
\hline
\end{tabular}

Table 6. Sewage treatment systems efficiencies (\%) estimated by using the optimization Model 5.

\begin{tabular}{ccccccc}
\hline & \multicolumn{7}{c}{ Location } & \\
\cline { 2 - 6 } Group & Ibatiba & Irupi & $\begin{array}{c}\text { N. S. } \\
\text { Graças }\end{array}$ & $\begin{array}{c}\text { St. } \\
\text { Trindade }\end{array}$ & Iúna & \\
\hline 1 & 95 & 82 & $<25(1)$ & $<25(1)$ & 93 & 272 \\
2 & 95 & 73 & $<25(1)$ & $<25(1)$ & 66 & 236 \\
3 & 95 & 27 & $<25(1)$ & $<25(1)$ & 67 & 191 \\
\hline
\end{tabular}

Table 7. Sewage treatment systems efficiencies (\%) estimated by using optimization Model 6.

\begin{tabular}{ccccccc}
\hline & \multicolumn{5}{c}{ Location } & \\
\cline { 2 - 6 } Group & Ibatiba & Irupi & $\begin{array}{c}\text { N. S. } \\
\text { Graças }\end{array}$ & $\begin{array}{c}\text { Trindade } \\
\text { Trind }\end{array}$ & Iúna & \\
\hline 1 & 95 & 90 & $<25(4)$ & $<25(2)$ & 95 & 286 \\
2 & 95 & 73 & $<25(4)$ & $<25(2)$ & 94 & 264 \\
3 & 95 & 27 & $<25(3)$ & $<25(1)$ & 84 & 210 \\
\hline
\end{tabular}

The optimization model 4 aimed to minimize the difference that the specific point organic loads and the square of the efficiencies estimated for the wastewater treatment plants so that the ratio of the i-th efficiency and average efficiency could be as close as possible of the square of the ratio between the organic load of the $\mathrm{i}$-th release point and the average load discharged in the river basin. Table 5 shows the results obtained by optimization Model 4 .

Optimization Model 5 sought to minimize the inequities between adjacent points, so that the ratio between organic load and efficiency for two neighboring points could be as close as possible, trying to establish an efficiency value not only related to the organic load but also consistent with its surroundings, where the released sewage presents most influence. These results are summarized in Table 6.

Model 5 simulations resulted in very different efficiencies for the municipality of Iúna sewage treatment system, resulting in lower sum of efficiencies values, when compared to Model 4 simulations. The model sought to minimize the inequity between adjacent loads. The fact that the nearest town to Iúna city is Nossa Senhora das Graças district probably caused decrease in the wastewater treatment efficiency estimated for Iúna.

Model 6 optimization sought to minimize the sum of differences correspondig to the ratio between point organic load and efficiency and the ratio between average load and average efficiency for the basin. The results from the application of this model are presented in Table 7 .

The results associated with optimization Model 1 indicated that the sewage produced by Iúna could be discharged in raw conditions without violation of the limits recommended by CONAMA Resolution 357/2005. Therefore, Iúna was the place presenting the highest variation of estimated efficiency values. The estimated efficiency values were increased substantially by the inclusion of equity relationships as restrictions (models 2 and 3) or for composing the objectives functions (models 4, 5 and 6), being respected environmental quality standards.

The results from simulations employing optimization models 4, 5 and 6 were close. When considering sets of lower efficiencies associated with the simulations groups 2 and 3, the differences did not exceed 4\%.

The DO and BOD profiles for Pardo and Pardinho rivers, considering the discharge of sewage treated with the efficiencies estimated by using optimization Model 6, are presented in Figures 7 and 8 .

Table 8. Accumulated percentages required for the drawing of the Lorentz curve for the Model 4 optimization, group 2 simulations.

\begin{tabular}{|c|c|c|c|c|c|}
\hline Location & $\begin{array}{l}\text { Organic load } \\
\quad\left(\mathrm{kg}^{\left.-\mathrm{d}^{-1}\right)}\right.\end{array}$ & $\begin{array}{l}\% \text { Cumulative of } \\
\text { Organic Load }\end{array}$ & Efficiency & $\begin{array}{c}\text { Removed } \\
\text { Organic Load } \\
\left(\text { kg.d }^{-1}\right)\end{array}$ & $\begin{array}{c}\text { \% Cumulative } \\
\text { Organic Load } \\
\text { Removed } \\
\end{array}$ \\
\hline & & 0.00 & & & 0.00 \\
\hline St.Trindade & 11 & 0.63 & 1 & 0.11 & 0.0001 \\
\hline N.S.Graças & 22 & 1.89 & 1 & 0.22 & 0.0140 \\
\hline Irupi & 180 & 12.22 & 73 & 131.40 & 8.34 \\
\hline Iúna & 690 & 51.80 & 94 & 648.60 & 49.43 \\
\hline Ibatiba & 840 & 100.00 & 95 & 798.00 & 100.00 \\
\hline SUM & 1743 & & & 1578.33 & \\
\hline
\end{tabular}


By simple inspection of Figures 7 and 8, it can be observed that the possible disposal of sewage treated by a sewage treatment plant presenting the minimum efficiencies estimated by optimization Model 6 would not violate the water quality restrictions for the use class. The same behavior was observed for the final treated effluent disposal simulations considering the sets of efficiencies tested by the other optimization models.

It is important to note that Pardinho river presented BOD concentrations close to the maximum limit established by CONAMA Resolution 357/2005, indicating that the estimated effluent treatment efficiency was the smallest possible for meeting the environmental quality requirements. The effluents discharged in the Pardo river would be treated in such a a way that the simulated BOD concentrations would be very lower than the maximum indicated by legislation. This condition resulted from the attempt to achieve equity among treatment efforts.

\section{Lorentz curves}

In this work, the distribution of sewage treatment efforts among different release points located in the watershed was analyzed considering that a fair distribution would be one by which larger production of organic loads should correspond to higher levels of sewage treatment.

Considering the studied optimization models, Model 1 did not show any equity measure composing the objective function or imposed as restriction on the optimization problem. However, the Lorentz curve was drawn for this model anyway in order to evaluate how little equitable it behaved. Optimization models 2 and 3 presented equity measures imposed as problem constraints. However, the equity condition among the proposed releases was no achieved by the referred models and, in function of this condition, the results of their application were not incorporated into the Lorentz curves. The use of optimization models 4, 5 and 6, that include equity measures in the objective function, allowed to obtain sets of efficiencies that do not necessarily guarantee achievement of similar equity conditions. In this context, it was considered relevant the use of Lorentz curves for comparing the equity levels reached by models 4, 5 and 6 .

From accumulated percentages, the Lorentz curves were determined on the basis of the raw organic load values, and treatment efficiencies generated by the AG values were used to calculate the amount of organic material removed at each point of sewage release and create, within river basin, the relationship between how much it is released and how much it is treated. Table 8 combines the values needed to build the Lorentz curve calculated by using Model 4 optimization, group 2 simulations results. Similar tables were produced for the other models and optimization groups.

Thus, Lorentz curves were built with the accumulated percentage of organic load discharged, on the $\mathrm{x}$ axis, and the cumulative percentage of organic load removed arranged, on the $y$ axis.

As an example, the Lorentz curves related to simulations Group 3 are shown in Figure 9.

Group 3 led to Lorentz curves a) more distant from each other and b) further from the perfect equity line, due to the larger
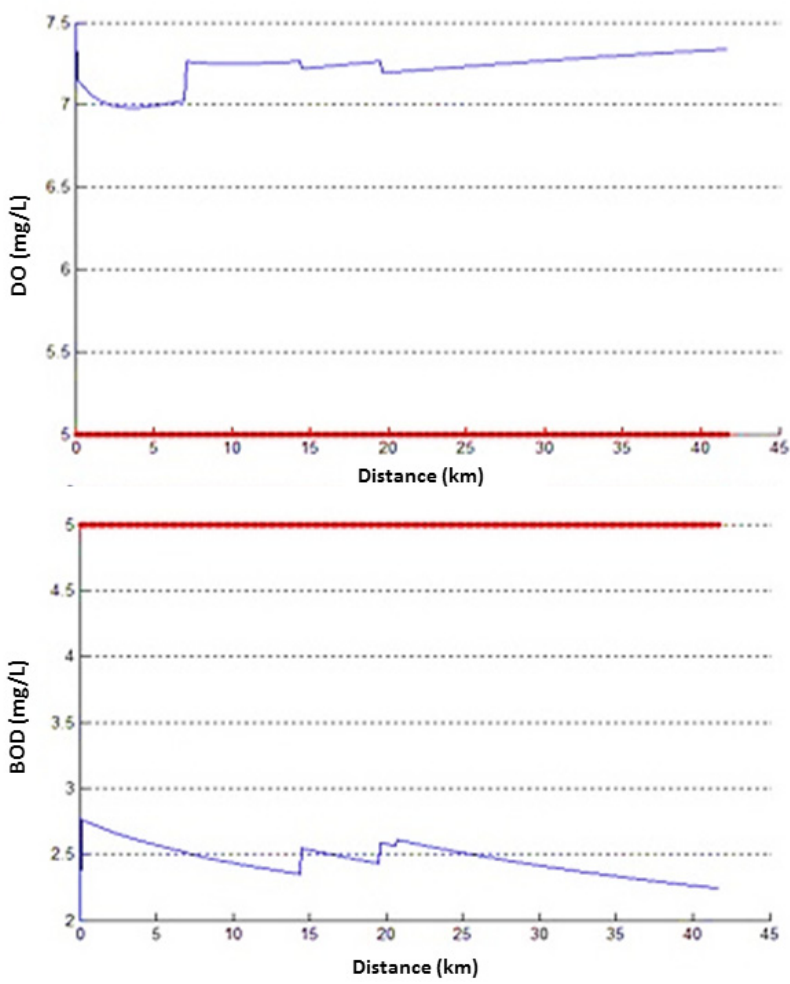

Figure 7. Pardo river DO and BOD concentration profiles.
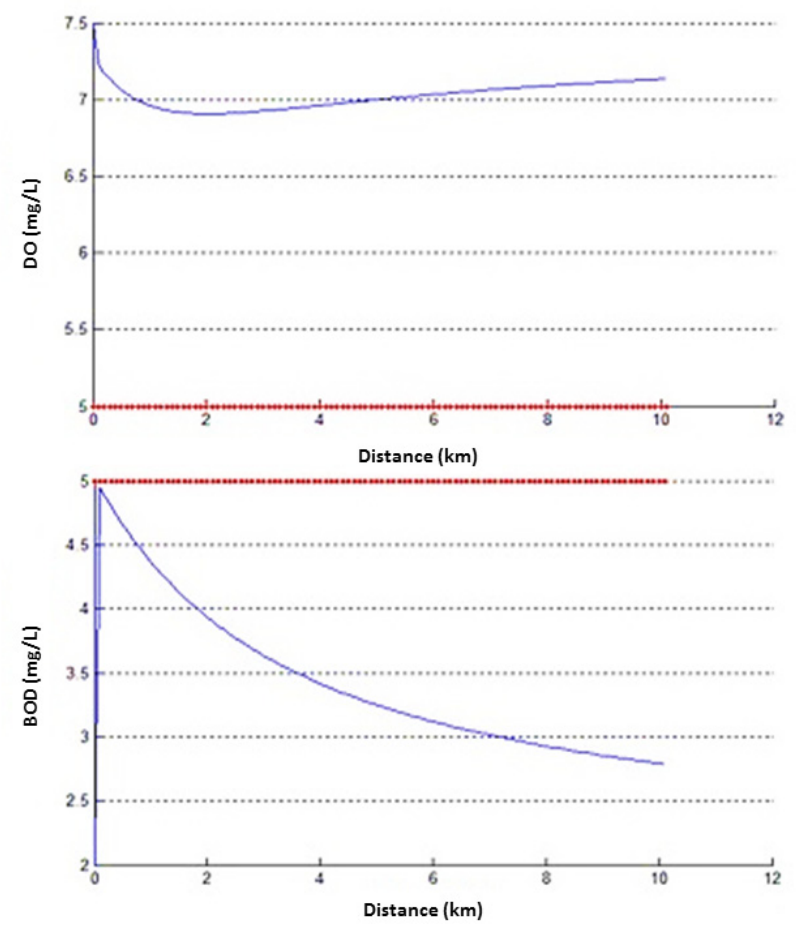

Figure 8. Pardinho river DO and BOD concentration profiles. 


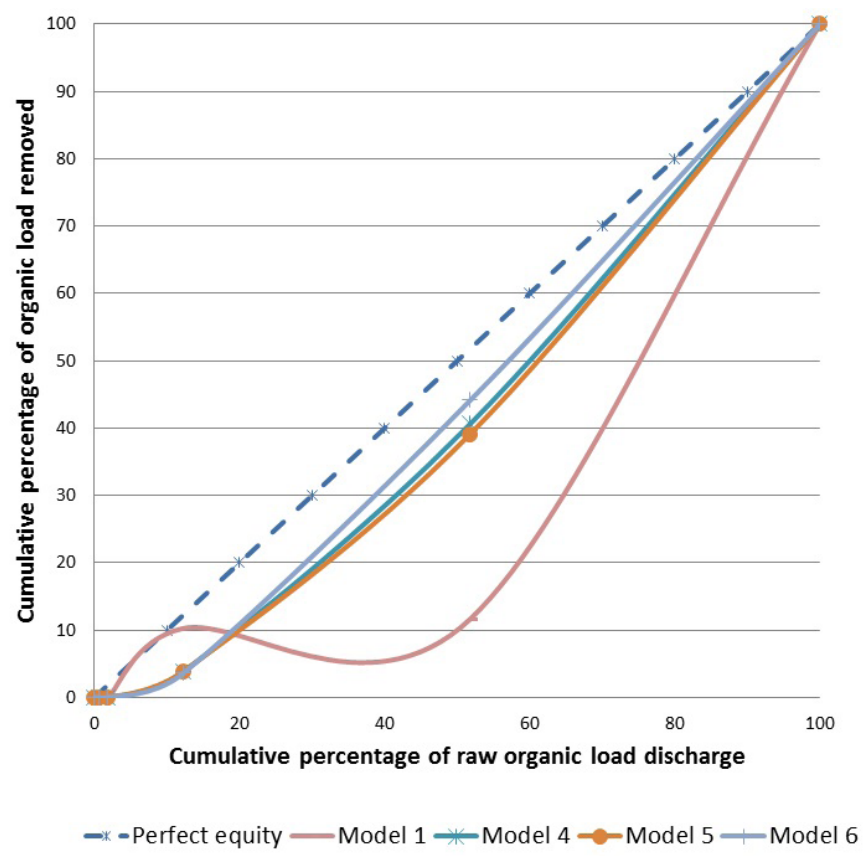

Figure 9. Lorentz curves associated with Group 3 simulations.

search space set - DO and BOD quality standards for CONAMA Class III use rivers. This condition allowed the AG greater variation in the estimated efficiency values.

Among the evaluated models, the optimization Model 5 led to the Lorentz curve farther from the perfect equity line. Model 6, in turn, was the one that most approached the perfect equity condition. As simulations Group 3 allows greater treatment efforts flexibility, the model that best achieve equity condition in this group of simulations tend to offer greater equity whenever appropriate search space for solutions exists.

\section{CONCLUSIONS}

The study sought to evaluate optimization models for determination of minimum sum of sewage treatment efficiencies in the Pardo river catchment area. The main reached conclusions can be summarized as follows:

- The lack of consideration of equity measure in the optimization Model 1 caused inadequate sewage treatment efforts distribution within the river basin. Most significant releases may be associated with lower levels of treatment than those indicated for inexpressive releases, when they are located in places where watercourses present higher self-purification capacities. This finding supports the view that the disregard of restrictions related to equity can lead to solutions that indicate that it would not be necessary implementation of treatment systems for cities that, generate large sewage loads, such as Iúna. Failure to sewage treatment system implementation in Iúna city would lead to higher taxation of other communities treatment, in order to maintain the Pardo river basin watercourses quality parameters respecting limits set by Brazilian CONAMA resolutions.
- Models 2 and 3, which present equity measures as established restrictions on the optimization problem did not show good performance when applied to the Rio Pardo basin due to the fact that the basin presents point raw organic loads releases presenting very different values. This condition did not allow attainment of efficiency values that ensured the equity conditions proposed by the models when environmental quality standards established by CONAMA Resolution 357/2005 were attended.

- Values of sums of Efficiencies obtained by the application of the Models 4, 5 and 6 were close. However, the use of the Lorentz curves indicated that the optimization Model 6 produced more equal distribution of wastewater treatment efficiencies, regardless of the simulations group considered.

\section{ACKNOWLEDGEMENTS}

The National Council for Scientific and Technological Development (CNPq) for conceding scholarship grant to the first research paper author.

\section{REFERENCES}

ALBERTIN, L. L.; MAUAD, F. F.; DANIEL, L. A. Uso de simulação computacional para planejamento de um sistema hídrico: estudo de caso qualitativo e quantitativo. Revista Brasileira de Recursos Hídricos, v. 11, n. 4, p. 209-219, 2006. http://dx.doi.org/10.21168/rbrh. v11n4.p209-219.

ANDRADE, L. N.; MAURI, R. G.; MENDONÇA, A. S. F. A general multiobjective model and a simulated annealing algorithm for waste-load allocation. Journal of Water Resources Planning and Management, v. 139, n. 3, p. 339-344, 2013. http://dx.doi.org/10.1061/ (ASCE)WR.1943-5452.0000257.

ARAS, E.; TOGAN, V.; BERKUN, M. River water quality management model using genetic algorithm. Enviromental Fluidic Mechanical, v. 7, n. 5, p. 439-450, 2007. http://dx.doi.org/10.1007/ s10652-007-9037-4.

BRASIL. Resolução CONAMA no 357, de 17 de março de 2005. Diário Oficial [da] República Federativa do Brasil, Brasília, DF, 17 mar. 2005.

BRASIL. Resolução CONAMA n 430, de 13 de maio de 2011. Diário Oficial [da] República Federativa do Brasil, Brasília, DF, 13 maio 2011.

BURN, D. H.; YULIANTI, J. S. Waste-load allocation using genetic algorithms. Journal of Water Resources Planning and Management, v. 127, n. 2, p. 121-129, 2001. http://dx.doi.org/10.1061/(ASCE)07339496(2001)127:2(121).

CALMON, A. P. S.; SOUZA, J. C. S.; REIS, J. A. T.; MENDONÇA, A. S. F. Uso combinado de curvas de permanência de qualidade e 
modelagem da autodepuração como ferramenta para suporte ao processo de enquadramento de cursos d'água superficiais. Revista Brasileira de Recursos Hidricos, v. 21, n. 1, p. 118-133, 2016. http:/ / dx.doi.org/10.21168/rbrh.v21n1.p118-133.

CARVALHO, R. C.; KAVISKI, E. Modelo de auxílio à tomada de decisões em processos de despoluição de bacias hidrográficas. Revista Brasileira de Recursos Hídricos, v. 14, n. 4, p. 17-27, 2009. http://dx.doi.org/10.21168/rbrh.v14n4.p17-27.

CHO, J. H.; LEE, J. H. Multi-objective waste load allocation model for optimizing waste load abatement and inequality among waste dischargers. Water, Air, and Soil Pollution, v. 225, n. 3, p. 1-17, 2014. http://dx.doi.org/10.1007/s11270-014-1892-2.

CHO, J. H.; SEOK SUNG, K.; RYONG HA, S. A river water quality management model for optimising regional wastewater treatment using a genetic algorithm. Journal of Environmental Management, v. 73, n. 3, p. 229-242, 2004. http://dx.doi.org/10.1016/j. jenvman.2004.07.004. PMid:15474740.

DRUCKMAN, A.; JACKSON, T. Measuring resource inequalities: the concepts and methodology for an area-based Gini coefficient. Ecological Economics, v. 65, n. 13, p. 242-252, 2008. http://dx.doi. org/10.1016/j.ecolecon.2007.12.013.

\section{EPA - UNITED STATES ENVIROMMENTAL PROTECTION}

AGENCY. Rates, constants and kinetics formulations in surface water quality modeling. Athens: EPA, 1985.

HOLENDA, B.; DOMOKOS, E.; RÉDEY, Á.; FAZAKAS, J. Aeration optimization of a wastewater treatment plant using genetic algorithm. Optimal Control Applications \& Methods, v. 28, n. 3, p. 191-208, 2007. http://dx.doi.org/10.1002/oca.796.

IBGE - INSTITUTO BRASILEIRO DE GEOGRAFIA E ESTATÍSTICA. Atlas de saneamento. Rio de Janeiro: IBGE, 2011.

MARSH, M. T.; SCHILLING, D. A. Equity measurement in facility location analysis: A review and framework. European Journal of Operational Research, v. 74, n. 1, p. 1-17, 1994. http://dx.doi. org/10.1016/0377-2217(94)90200-3.

MULLIGAN, G. F. Equality measures and facility location. Regional Science, v. 70, n. 4, p. 345-365, 1991. http://dx.doi.org/10.1007/ BF01434593.

NICKLOW, J. W.; REED, P. M.; SAVIC, D.; DESSALEGNE, T.; HARRELL, L.; CHAN-HILTON, A.; KARAMOUZ, M.; MINSKER, B.; OSTFELD, A.; SINGH, A.; ZECHMAN, E. State of the art for genetic algorithms and beyond in water resources planning and management. Journal of Water Resources Planning and Management, v. 136, n. 4, p. 412-432, 2010. http://dx.doi. org/10.1061/(ASCE)WR.1943-5452.0000053.

O'CONNOR, D. J.; DOBBINS, W. E. Mechanism of reaeration in natural streams. American Society of Civil Engineers Transactions, v. 123, p. 641-684, 1958.
PALIWAL, R.; SHARMA, P.; KANSAL, A. Water quality modelling of the river Yamuna (India) using QUAL2E-UNCAS. Journal of Environmental Management, v. 83, n. 2, p. 131-144, 2007. http:// dx.doi.org/10.1016/j.jenvman.2006.02.003. PMid:16697517.

PARK, D. K.; KO, N. Y.; LEE, K. K. Optimal groundwater remediation design considering effects of natural attenuation processes: pumping strategy with enhanced-natural-attenuation. Geoscience Journal, v. 11, n. 4, p. 377-385, 2007. http://dx.doi. org/10.1007/BF02857053.

PENN, R.; FRIEDLER, E.; OSTFELD, A. Multi-objective evolutionary optimization for greywater reuse in municipal sewer systems. Journal of Water Research, v. 47, n. 15, p. 5911-5920, 2013. http://dx.doi.org/10.1016/j.watres.2013.07.012. PMid:23932104.

REIS, J. A. T.; VALORY, J. L.; MENDONÇA, A. S. F. Seleção de eficiências de tratamento de esgotos a partir da manutenção de equidade entre sistemas de tratamento: uma abordagem para o gerenciamento de bacias hidrográficas. Revista Brasileira de Recursos Hídricos, v. 20, n. 4, p. 862-871, 2015. http://dx.doi.org/10.21168/ rbrh.v20n4.p862-871.

SAADATPOUR, M.; AFSHAR, A. Waste load allocation modeling with fuzzy goals; simulation- optimization approach. Water Resources Management, v. 21, n. 7, p. 1207-1224, 2007. http://dx.doi. org/10.1007/s11269-006-9077-4.

SALLA, M. R.; PEREIRA, C. E.; ALAMY FILHO, J. E.; PAULA, L. M.; PINHEIRO, A. M. Estudo da autodepuração do Rio Jordão, localizado na bacia hidrográfica do Rio Dourados. Revista Engenharia Sanitária e Ambiental, v. 18, n. 2, p. 105-114, 2013. http://dx.doi. org/10.1590/S1413-41522013000200002.

SUN, T.; ZHANG, H.; WANG, Y.; MENG, X.; WANG, C. The application of environmental Gini coefficient (EGC) in allocating wastewater discharge permit: the case study of watershed total mass control in Tianjin, China. Resources, Conservation and Recycling, v. 54, n. 9, p. 601-608, 2010. http://dx.doi.org/10.1016/j. resconrec.2009.10.017.

TEODORO, A.; IDE, C. N.; RIBEIRO, M. L.; BROCH, A. O.; SILVA, J. B. Implementação do conceito capacidade de diluição de efluentes no modelo de qualidade da água QUAL-UFMG: estudo de caso no Rio Taquarizinho (MS). Revista Engenharia Sanitária e Ambiental, v. 18, n. 3, p. 275-288, 2013. http://dx.doi.org/10.1590/ S1413-41522013000300010.

THOMANN, R. V.; MUELLER, J. A. Principles of surface water quality modeling and control. New York: Harper \& Row, 1987.

TSAI, M.; CHANG, C. Water usage and treatment network design using genetic algorithms. Industrial \& Engineering Chemistry Research, v. 40, n. 22, p. 4874-4888, 2001. http://dx.doi.org/10.1021/ie010011g.

VALORY, J. L.; REIS, J. A. T.; MENDONÇA, A. S. F. Combining genetic algorithms with a water quality model to determine 
efficiencies of sewage treatment systems in watersheds. Journal of Environmental Engineering, 2015.

VALORY, J. P. L. Aplicação combinada de método de otimização e modelo de qualidade de água na determinação de eficiências de sistemas de tratamento de efluentes domésticos: uma abordagem para o gerenciamento de bacias hidrográficas. 2013. 114 f. Dissertação (Mestrado em Engenharia Ambiental)-Programa de Pós-graduação em Engenharia Ambiental, Universidade Federal do Espírito Santo, Vitória, 2013.

VON SPERLING, M. Princípios do tratamento biológico de águas residuárias: estudos e modelagem da qualidade da água de rios. Belo Horizonte: Departamento de Engenharia Sanitária e Ambiental, Universidade Federal de Minas Gerais, 2007.

YANDAMURI, S. R. M.; SRINIVASAN, K.; BHALLAMUDI, S. M. Multiobjective optimal waste load allocation models for rivers using nondominated sorting genetic algorithm-II. Journal of Water Resources Planning and Management, v. 132, n. 3, p. 133-143, 2006. http://dx.doi.org/10.1061/(ASCE)0733-9496(2006)132:3(133).
ZHANG, R.; QIAN, X.; LI, H.; YUAN, X.; YE, R. Selection of optimal river water quality improvement programs using QUAL2K: a case study of Taihu Lake Basin, China. The Science of the Total Environment, v. 431, p. 278-285, 2012. http://dx.doi.org/10.1016/j. scitotenv.2012.05.063. PMid:22687438.

\section{Authors contributions}

Mariana Coelho Santoro: Acquisition of data, selection of optimization models, water quality simulation, determination of treatment efficiencies, analysis and interpretation of results, drafting of manuscript and critical revision.

José Antonio Tosta dos Reis: Analysis and interpretation of results, drafting of manuscript and critical revision.

Antonio Sérgio Ferreira Mendonça: Analysis and interpretation of results, drafting of manuscript and critical revision. 